\title{
PRESENTATION OF THE INTERNATIONAL WOMEN'S DAY IN THE SERBIAN PRESS
}

\begin{abstract}
One's attention is directed to the events, phenomena, personalities and social groups present in the media. How they are perceived depends on media presentation and representation, which implies media representations of events, phenomena, identities, social groups. Through them, the media can shape public opinion, refer to or restrict stereotypical and discriminatory attitudes in society. One of the fundamental conditions for combating discrimination is equal participation of women in the media world, i.e. the equal presence of women and men in the media. The paper investigates the presence of women in the following daily newspapers: Politika, Danas, Blic, and Večernje novosti on International Women's Day, with special reference to the method of reporting on this holiday. The theoretical part of the paper includes a chapter on the social status of women throughout history, outlining some of the factors for the inferior position of women that contributed to the creation of stereotypes about women. Then, attention is paid to stereotypes about women, dominant patterns of reporting on women in the media, as well as the importance of the holiday and its historical origin. The interpretation of previous research in published scientific papers can also be found in the theoretical part. The second part of the paper includes the quantitative and qualitative research results. Finally, the results are summarized, which leads to the conclusion.
\end{abstract}

Key words: media, International Women's Day, marginalization, stereotypes, media representation

\section{Introduction}

With the gradual development of the media, their power of influence on society developed too. Media content, which initially targeted a selected and small audience, is created today for the purpose of reproduction for mass audiences. Radovic and associates point out that they are journalists interpreters of reality, guardians of the public interest and, since the beginning of mass communication, a kind of the conscience of society (Radović et al., 2014: 80). The media encourage and influence thinking about and forming opinions on the topics covered by them. „The media are potentially powerful agents that can affect behaviour and attitudes, whether intentionally or not, giving rise to claims of harm“ (McQuail, 2005: 242). By selecting topics (agenda setting ${ }^{3}$ ) which are the subject of

\footnotetext{
${ }^{1}$ Received March 2020/ Accepted May 2020

${ }^{2}$ E-mail: 95nikolica@gmail.com

3 " Agenda setting is a mass media theory that is based on the premise that mass media have a great influence on the audience by choosing what to publish and how much space to give to selected events, occurrences, or figures" (Price, 2011: 69).
} 
media coverage, the attention of the audience is directed to certain events, ideas, and often to propaganda messages. Media texts do not give equal importance to all social groups, thus marginalizing certain groups. Vujovic and associates claim that media texts testify to the distribution of power, differences and position of social and other groups, and about their invisibility and marginalization (Vujović et al., 2014: 107, 108).

Media coverage, especially in tabloids, is often not based on one of the basic principles of journalism - the principle of objectivity. Instead of objective fact-based reporting, the media shape the information and produce meaning. Briggs and Cobley state that the manner in which the media present things is not only their "reflection", but also the assignment of meaning to these things, and is considered "the cause of our social relations" (Briggs, Cobley, 2005: 470). The power of the media is such that they can also be defined as creators of reality. Višnjić points out that power relations within different social communities also reflect the "media distortion of reality", which means the "media distortion of either 'real' gender or the 'real' meaning of gender that exists 'out there" (Višnjić, 2016: 13). Media representation can also be discussed. Stuart Hall points out that media representation implies the active work of selecting and presenting, of structuring and shaping. It does not imply the transmitting of an already existing meaning, but the more active labour of making things mean. It was a practice, a production, of meaning, what subsequently came to be defined as a 'signifying practice', and that power of the media should be taken seriously (Hall, 1982: 60). Instead of presenting reality, the media shape it according to their own interests or in accordance with the interests of dominant groups and powerful people, thus fabricating reality. In the scientific paper "Visual Representation of Women in the Women's Press", Vujović points out that representation always implies the existence of ideas, interests, intentions and ideology (Vujović and Milovanović: 2014: 123). The media represent certain identities, and the manner in which they do that influences the creation of a positive or negative image of certain social categories. "Why is it important how the media represent certain identities? First of all, because the process of representation cannot be considered separately from reality, since thanks to it, our experience and the whole cognitive world make sense (Slavnić, 2011: 16). The representation of women's identity in the media is often stereotypical and discriminatory compared to men's identity. Vujović and associates point out that numerous studies show that the media marginalized women and stereotypically report on them (Vujović et al., 2014: 108).

The number of media texts about women, the manner in which they are presented to the public, as well as the choice of topics point to two facts: the status of women in society, and the creation of a certain opinion about women, that is, encouraging society to think about women in a certain way. "The media represent public life, mainly through debate and dialogue, and show what is currently happening in society. If you are not in the media, you do not exist. It is therefore important from the perspective of equal rights that women and men can "occupy" the media space on the same terms" (Višnjić, Mirosavljević, 2008: 248).

Women's rights have been suppressed throughout history, which is why women's resistance emerged in the early $20^{\text {th }}$ century, with the celebration of International 
Women's Day. Given the power of the media in society, the manner in which it is reported on the holiday traditionally celebrated on the eighth of March is of great importance. Based on the research that will be conducted in relation to the holiday, the model of reporting on International Women's Day in the Serbian daily press will be determined.

\section{Theoretical Framework}

\subsection{Social Status of Women Throughout History}

Gender inequality has been present for centuries throughout social history. The position of women today is conditioned by the cultural and traditional patterns spread over time, thereby repeating and continuing the subordination of women. The perception of women as inferior beings is a result of historical events, regulations, laws and patriarchy, which still influence the denial of women's rights. "A woman labeled as the pillar of the family is naturally predisposed to the role of mother, wife, housewife, while being culturally conditioned to inferiority" (Vujović at al., 2014: 110). The characteristics of the patriarchal society are noticeable even today, despite the progress of civilization, the realization of some of women's rights, and the ever increasing social aspirations for gender equality.

Throughout history, the political inequality of women compared to men was also prominent, which is exactly why the first International Women's Day was celebrated. Political passivity and complete voting discrimination against women remained in the world until the end of the $19^{\text {th }}$ century. According to author Sinko, women are first time obtained the right to vote in New Zealand in 1893 (Šinko, 2007: 72). Balkovec wrote about the position of women and their political rights in Yugoslavia. He points out that after the First World War, women became politically recognized entities, which national radicals strongly opposed, believing that it was first necessary for women to fight for other rights, such as equal salary compared to men. The author further states that women were considered incapable of independent reasoning and subjected to different influences. Family disintegration was feared and warned of (Balkovec, 2016: 200, 201). This, once again, illustrates the role of women as pillars of the family. In some countries, women's suffrage was exercised much later. In Switzerland, this happened only in 1971, and Vuković states that women were often apathetic in the 1990s when it came to interest in politics, both in terms of participation in the elections, and participation in political discussions. Vuković points out that all this did not contribute to women's significant political activism and to their broader interest in politics (Vuković, 2009: 26-27).

Immediately after the exercise of women's suffrage in Yugoslavia, the role of women as "workers" emerged. However, it was the role of women as unskilled workers, doing jobs that could not contribute to improving the social position of women. Zaharijevski according to Pilić states that in the period between 1920 and 1925 , the number of employed men increased by only $9 \%$, while the number of 
employed women increased by $95 \%$. The industry relied on the exploitation of cheap women's labour, and the agrarian nature of the economy and the limited conditions of industrialization contributed to a far worse position of women in our country at that time than in the commodity and industrial production in European countries (Pilić according to Stjepanović-Zaharijevski, 1999: 103). Even today, the working environment is unfavorable for women. Melki and Farah write about the unfavorable work environment for women journalists. They state that gender discrimination and sexual harassment remain overlooked taboos, especially in the news media workplace. They points out that strong social and institutional factors prevent many women from entering journalism and the media field, discourage them from enduring in this career and prevent them from advancing in their positions. For the unequal position of a woman, the authors point out lack of laws, codes of professional conduct and enforcement mechanisms to protect and empower women. Possible solutions to combating gender discrimination, according to Melki and Farah, are: including critical media literacy and gender studies in the curriculum; working toward developing and enforcing institutional policies that discourage gender discrimination and sexual harassment and provide a work environment more conducive to women; working toward developing legal codes that specifically criminalise gender discrimination and sexual harassment and adding explicit language in the codes of professional conduct championed by press and media syndicates that address these matters; forming a professional group devoted to promoting and advancing gender equity in newsrooms (Melki, Farah, 2014: 75-77). The lack of the law, which would regulate some of women's rights, is also written by author Vasiljević. Author points out that laws governing the work of the media do not oblige the media for non-sexist reporting and for the balanced representation of men and women, nor do they stipulate equal participation of women and men in decision-making places in the media (Vasiljević, 2009: 35).

The aforementioned gender inequalities throughout history reflect the inferior position of women, which has partly persisted in today's society. They are also the basis for the creation of stereotypes about women, while they are spread and strengthened through the media.

\subsection{Stereotypes About Women}

According to Milošević, the concept of stereotype was introduced into science by Walter Lippmann in 1922 (Milošević, 2004: 96). Stereotypes are often generalized, simplified and distorted mental images of a particular social group. Hall points out that stereotyping reduces people to a few, simple, essential characteristics, which are represented as fixed by nature. Stereotypes get hold of the few vivid, memorable, easily grasped and widely recognized characteristics about a person, reduce everything about the person to those traits, exaggerate and simplify them, and fix them without change. Secondly, as Hall states, stereotyping deploys a strategy of splitting. It divides the normal and the acceptable from the abnormal and the unacceptable and excludes or expels everything which does not fit, which is different (Hall, 2001: 257, 258). Stereotypes can also be positive, though they are mostly negative, arising among 
other things, from culturally based patterns of behaviour towards a particular social category. "Cultural barriers 'petrified' in stereotypes are a huge problem that prevents full inclusion" (Petrović according to Petrović, 2012). They are based on unfounded facts and claims, and often arise from ignorance. They can also be defined as beliefs that label certain social groups. Lippmann states that stereotype patterns are not neutral. A stereotype is a projection of our sense of our value, of our position and our rights, into the world. According to Lippmann, stereotypes are, therefore, highly charged with feelings that accompany them, and they represent the fortress of our tradition (Lippmann, 1956: 96). A more precise definition of stereotype is given by Kuzmanović, who implies under a stereotype a schematic and rigid representation of the personality and behavioural patterns of a member of some group, which is rigidly spread and used as a pre-created image of almost any individual in that group (Kuzmanović according to Milošević, 2004: 96).

Stereotypes related to male and female gender are called gender stereotypes, and the authors define them as follows: "Gender stereotypes are beliefs about typical psychological characteristics and behaviour of women and men. Therefore, it is not just the male-female label/categorization, but the assumptions about the characteristics and behaviour of members of a particular gender" (Penezić, Šunjić, 2013:79).

The media are involved in spreading gender stereotypes with such representation of women that promotes archaic division of roles and archaic values for women. The authors point out that the media today strongly reflect, represent, and construct stereotypical roles and identities defined by conservative patriarchal ideology. The portrayal of women, as the authors state, has always been one of the most common stereotypes, and these are well-known stereotypes - a woman is weak, absent, unable to make decisions, but beautiful and able to serve (Juka, Bilaver, 2013: 24). Some of the most common stereotypes about women are the following: noticeable sensitivity and weakness in women, bad executives, unskilled drivers, obsessed with their appearance, not good enough in politics, the stereotype of blond women, of women as "gossipers", not capable or independent enough, not doing "male" jobs well enough, etc. Montiel states that media content reproduces sexist stereotypes that associate male identity with domination, independence, power, while women are depicted as emotional, vulnerable, sensitive and dependent upon male actions (Montiel, 2014: 17). The traditionally based division into "male" and "female" jobs has produced a special type of stereotype that is reflected in almost all societies. Throughout history, household chores were intended for women, and hence the social attitude that a woman's place is at home. Zaharijevski writes about the civic stereotype, which implies that the right place for women is home, it was determined by nature for the woman. In terms of existence in the family, a woman is satisfied in the roles of a diligent housewife, a devoted wife and a hard working mother (Zaharijevski, 1999: 105). 


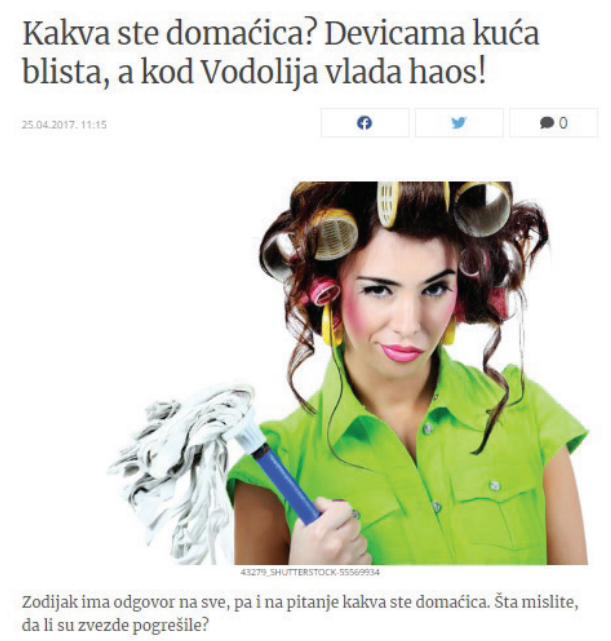

Example of stereotyped headline from Blic Žena

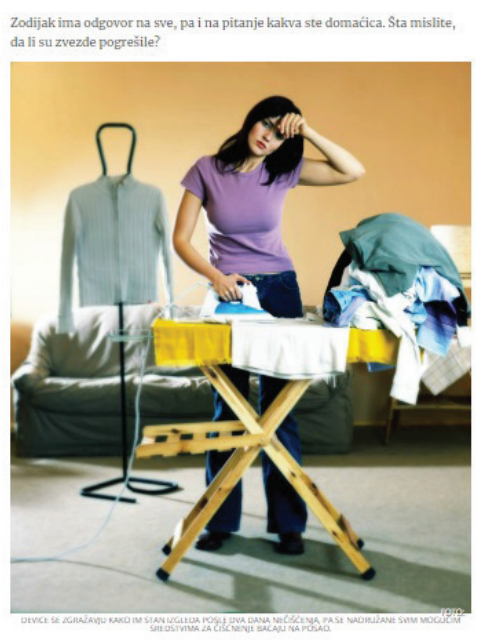

Example of stereotyped photo from same article

The general opinion is that women voluntarily accept and even enjoy the aforementioned roles, which could be labelled as another stereotype in the already existing stereotype. Thus, there is a stereotype about roles, but also a stereotype about enjoying them. "It will be said, the rule of men over women differs from all these others in not being a rule of force: it is accepted voluntarily; women make no complaint, and are consenting parties to it" (Stuart Mill, 2000: 24). Such views have long been historically grounded. Various interpretations and definitions were a prerequisite for creating a subordinate position of women. The creation of the stereotype of women as housewives was influenced by the separation of private and public spheres. According to Zaharijevski, the traditionalist civic theory sharply separates private and public, placing women in the sphere of private, where she performs only feminine roles and thus contributes to the stability of the family. A woman as a public being does not exist, the civic formula for women is "Church-Children-Kitchen" (Zaharijevski, 1999: 105).

Social and historical events have played a major role in establishing the position of women, but also in creating stereotypes. It depends on the media culture how much these stereotypes will be present in society. In a world surrounded by the media, the manner of reporting on stereotyped groups is of great importance.

\subsection{Image of women in the media}

One's attention is directed to the events, phenomena, personalities and social groups present in the media. How they are perceived depends on media presentation and representation, which implies media representations of events, phenomena, identities, social groups. Through them, the media can shape public opinion, refer to or restrict stereotypical and discriminatory attitudes in society. Some of the conclusions of Denis McQuail, in a paper entitled „The influence and effects of mass 
media", are: mass media do have importnant consequences for individuals, society and culture, and are a strong instrument of social power; the media can attract and direct attention to problems, solutions or people in ways which can favour those with power and divert attention from rival individuals or groups; the media can help to bring certain kinds of publics into being and maintain them; the mass media can confer status and confirm legitimacy (McQuail, 1977). One of the fundamental conditions for combating gender discrimination is equal participation of women in the media world, i.e. the equal presence of women and men in the media. The media should be a forum for the equal visibility of both genders. The authors point out that the mass media in the world are still indicators of male domination, although there is confirmation that women gradually are conquering the media space and professions (Višnjić, Mirosavljević, 2008: 248). The presence of women in the media does not correspond to the real picture - the fact that women make up half the population. Montiel states that only $24 \%$ of news subjects are women, $76 \%$ are men. Representation of gender in news is associated with relations of domination and subordination. Men are represented as sportsmen, politicians and businessmen, women are represented as vox populi, and characterized by a lack of status and power (Montiel, 2014: 17). The absence of women in the media also confirms the research conducted by Vujović and associates, who analyzed the Serbian daily press. The results of the analysis showed alarming state of invisibility of women in serious columns, as well as invisibility in general (Vujović et al., 2014: 113). Data and percentages provided indicate that the media does not consider equal agenda setting (agenda setting theory) when it comes to male and female gender. By interpreting the definition of the agenda setting theory, which indicates that the media has a great influence on the audience by choosing the topics, personalities or social groups they report, it can be concluded that the media marginalization of women adversely affects the formation of social awareness of the position and status of women. Therefore, it is necessary to point out to the media the importance they have in society when drawing up a daily schedule.

However, in addition to their presence, the representation of women in the media is especially important, as well as the context of reporting on women. When it comes to serious political and economic topics, women are marginalized. According to Begović, Baćanović points out that the media have a major, almost crucial role in the recognition and visibility of women in politics. The media influence the quantitative presence and qualitative representation of women in politics. They can affect change in the attitude of voters, rejection of stereotypes and positive promotion of women as equal participants in political processes (Baćanović according to Begović: 2016: 65). Thus, the media could encourage society to think about women in a different way, and contribute to the rejection of stereotypes about women. Still, women appear more in entertainment columns, as objects that attract attention in an inappropriate manner, with elements of sensationalist reporting. "Even today, women are reduced to objects, and this can easily be concluded by looking at the Serbian print media" (Torlak, 2011:39). The portrayal of a woman as an object in the media indicates that she is not a protagonist, the creator of a media text, but only the object of reporting. 
In this way, her role is passive in that the content does not come from the opinion or will of the woman, but rather the story is shaped and built around her as an object. Sarikakis states that in everyday media the female body continues to be a revenue source and appears in entertainment roles (soft news, fashion etc.), and the role of men is as an experts (e.g. politics, science). That present a established practice and that is hard to change. (Sarikakis, 2014: 67).

Vujović and associates wrote about women portrayed as sexual objects in the press, and they state that the woman was portrayed in the media as a young, thin, naked, almost perfect and idealized. This creates a media image of women that does not correspond to reality, but is a kind of simulacrum that suggests to the male audience that only such a woman is a beautiful woman (Vujović et al., 2014, 110, 111).

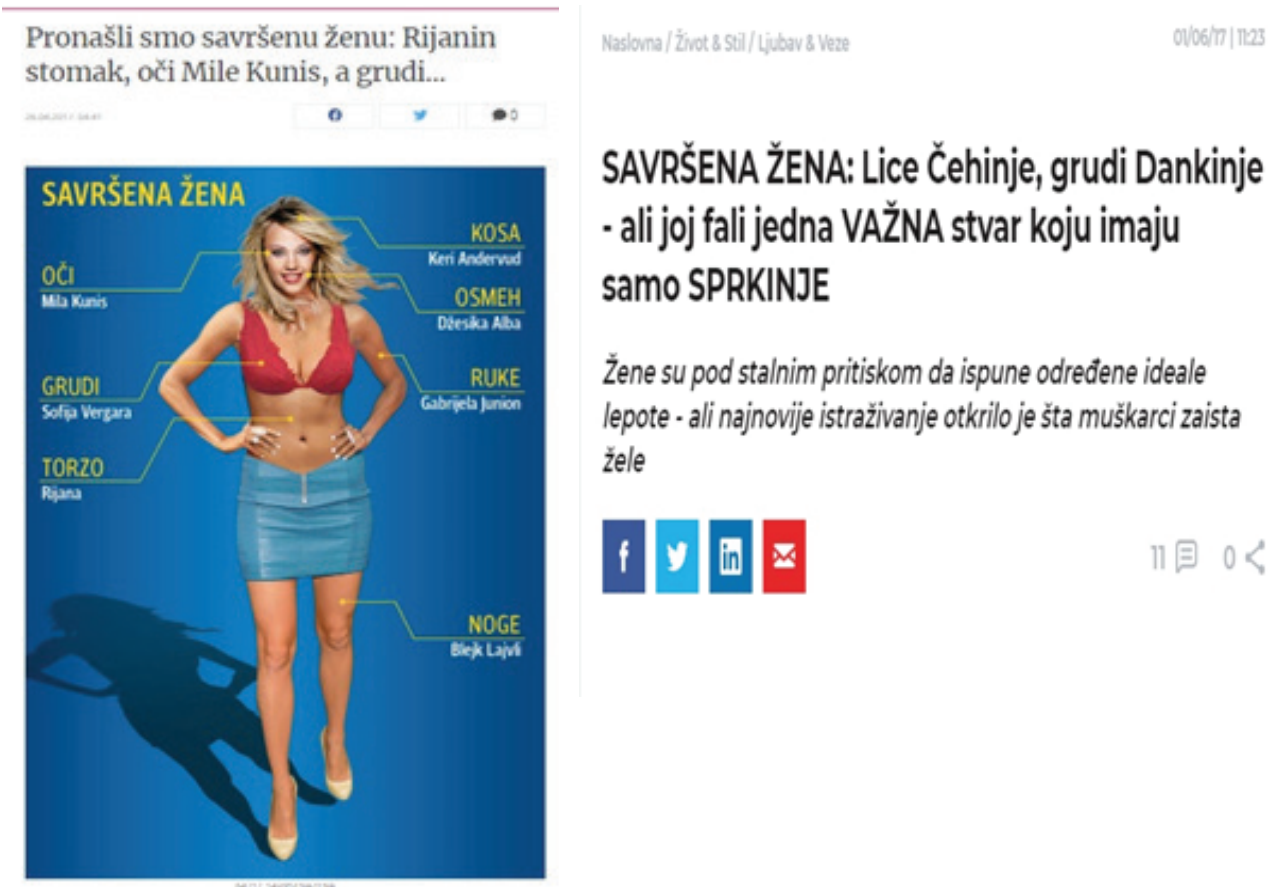

A model of the ideal look imposed on women by the media (First photo source zena.blic.rs; Second photo source telegraf.rs)

In addition to the media's portrayal of women as objects and their marginalization in the politics and economy sections, the media also influence the spread of misogynist ${ }^{4}$ attitudes. Juka and Bilaver state that the misogynistic elements and attitudes, inherited from the matrix of society, can be found in the media. In the media, women are conveyers of other people opinions rather than protagonists of events (Juka, Bilaver, 2013: 25). The ambivalent state of affairs in the media

\footnotetext{
4 "Misogyny is defined as hatred or animosity towards women. The misogynistic sentiment, misogyny, certainly belongs to the pathology of animosity towards women" (Berković, 2009: 309).
} 
caused by such reporting on women can also be discussed - on the one hand, the woman is portrayed as beautiful, young, thin, "almost perfect", and on the other, misogynistically portrayed as a perpetrator of a crime, condemned and criticized. In her Ph.D. dissertation, Vujović cites the results of the research conducted by "Ženski Indok Centar", which confirm the ambivalent attitude of the media towards women. Vujovic points out that the results obtained by this organization, among other things, show that women are the least represented in politics and economy, and most in the subculture. Women are portrayed as beautiful, white, heterosexual, urban, and on the other hand, attached to family and tradition; a good girl or mother of several children and a perfect wife. There appears the greatest number of articles about women when they are involved in an affair or murder, harshly condemned and criticized, while praise and rewards remain on the margins, reduced to two to three sentences. Women are mentioned or written about in only $31 \%$ of published articles in the print media (Vujović, 2016: 216).

Marginalizing women, spreading misogynistic attitudes, and portraying women as objects are indicators of the direction of the print media in Serbia when it comes to reporting on women. In the research study of the selected Serbian daily newspapers, the current state of affairs when it comes to the presence of women will be determined. The issues of the daily newspapers prepared for March $8^{\text {th }}$ (International Women's Day) will be analyzed, with special emphasis on the holiday.

\subsection{March $8^{\text {th }}-$ International Women's Day}

“The idea of celebrating March $8^{\text {th }}$ (February $23^{\text {rd }}$, according to the old calendar) as International Women's Day came from the activist of the German Social Democratic Party - Clara Zetkin, who brought it up at the International Conference of Socialist Women in Copenhagen in 1910. Initially, the holiday was supposed to reflect the fight of women for equal rights, in the first place - for the right to vote" (Baćević, 2007: 80). Before that, back in the 19th century, the rebellion of female workers at a textile factory in New York over low wages and inhumane working conditions, March 8,1857 , was a precursor to the holiday International Women's Day. Their protest was quickly stifled, but it encouraged the formation of the first women's union at a time when union movements were extremely critical of women's equal representation and demands (Zaharijević, Lončarević, 2011: 3). However, the original idea behind the holiday has become neglected over time. Its importance, reflected in the fight of women for equal rights, has been suppressed by the patriarchal patterns, according to which the role of a housewife "belongs" to women. The author states that during the 1960s and 1970s, International Women's Day lose its combative and ideological connotation. Instead, gender roles are celebrated that were considered most valuable in the patriarchal system - the role of a wife or spouse, and mother. (Baćević, 2007:

\footnotetext{
${ }^{5}$ According to the author, "Ženski Indok Centar" is an organization that has been monitoring the print media for ten years. It monitors several of the most circulated daily and weekly newspapers, and in its research, it annually processes over five thousand articles reporting on women in all spheres (Vujović, 2016: 216).
} 
81). Thus, the deeply rooted power of patriarchy has prevented women from fighting for gender equality. According to Baćević, Malešević points out that women are beginning to return to their traditional roles of the 1960s. With the withdrawal of women from public life, the return to home and the roles that emerge from that environment, the Eighth of March has gradually moved away from its original orientation and changed its meaning and content. In place of the former "fighting" day, it transformed in the sixties into the Mother's Day, a holiday of the parent and educator (Malešević according to Baćević, 2007: 81). The celebration of International Women's Day continued in the $21^{\text {st }}$ century, but not with the original idea - the fight for equal rights. The authors point out that at the beginning of the 21st century in Serbia, Women's Day in the public and media sphere becomes a holiday of secondary importance, whose "celebration" a large number of women reject. Women's Day is perceived as Mother's Day. The day is celebrated with gifts and talks about women as employed or unemployed mothers, caring wives and carers. Such a view becomes desirable and acceptable in the public and media spheres, and no topics are discussed on the economic and political situation of women in Serbia (Zaharijević, Lončarević, 2011: 7, 8). Although in many countries women obtained the right to vote, gender equality has not been fully achieved. Nonetheless, the holiday has been given a new symbolism, which does not include the idea of "fight". Baćević points out that this holiday reproduces stereotypical conceptions of gender roles, and she distinguishes the following customs and symbolism at the "celebratory level" of this holiday: giving flowers, organizing women-only trips or excursions, as well as celebrating the Eighth of March with festive dinners or lunches, in the presence of colleagues from work or family (Baćević, 2007: 81). In this way, the initial efforts for gender equality have been replaced by celebration and apparent affection towards women, which can be defined as the 'tacit' ignorance of social issues. Colović defines the holiday metaphorically: "The streets are crowded with cavaliers and ladies, flowers - a symbol of their affective, festive attitude. This is, according to the convenient formula found this year, a day for "men's niceness". (...) The close association between petals and skin appears as a giant sign of International Women's Day, its basic tone, the main feature. Newspapers unmistakably found the most comprehensive definition of this holiday: "International Women's Day - Flower Day" (Colović, 1972: 895).

The idea of this paper is to examine whether the print media in their issues published on the day of the holiday indicate to the public the original significance of International Women's Day or portray the holiday at the "celebratory level", according to Baćević.

\section{Methodological Framework}

The subject of this research is articles of different genres published in the Serbian daily press on International Women's Day, and the frequency of reporting on women on the said holiday. 
The main objectives of this paper are to determine the frequency of articles about International Women's Day, the manner of reporting on the holiday, as well as the general presence of women in daily newspapers on the day of the holiday.

The research methodology is based on specific operational method, quantitative content analysis of four selected Serbian daily newspapers - Politika, Danas, Blic, Večernje novosti. The analyzed daily newspapers differ in their editorial policy. Politika and Danas belong to the category of informative daily newspapers, while Blic and Večernje novosti are semi-tabloids. The selection covers different editorial policies in order to show potential differences among them.

Given that the subject of the analysis is International Women's Day, the issues of the above-mentioned daily newspapers prepared for March $8^{\text {th }}$ (the day of the celebration of the holiday), 2019 were analyzed.

A unit of analysis is every signed or unsigned newspaper article with a headline, regardless of its length and genre. Advertisements, announcements and classifieds were not considered as units of analysis, but were taken into account. It is important to note that a number of news items under a common headline were considered to be one article (such as "Tema dana" (eng. Top news) or "Tvitosfera" (eng. Twitter sphere), "Oko planete" (eng. Around the globe) in Blic; or "Među nama" (eng. Between us) and "Ukratko" (eng. In brief), which are the series of news items in Politika). An exception was made if there were different authors for each of the short articles. In this case, they were considered to be separate articles.

\section{Research Results}

A total of 333 articles were published in the four analyzed daily newspapers, 19 (and 3 advertisements) of which about International Women's Day, which is $5.71 \%$ of the total number of articles. Ninety-four articles (28.23\% of the total number) were about women.

A total of 62 articles were published in Politika. Five articles (and one advertisement) in this newspaper were about the holiday, which is $8.06 \%$ of the total number of articles in Politika. In this issue, 13 (20.97\%) articles about women were published.

A total of 83 articles were published in Danas, 11 (13.25\%) of which were about the holiday. In this issue, Danas published 22 (26.51\%) articles about women.

A total of 65 articles were published in Blic. No article indicated that the idea behind writing it was the holiday. In this issue of Blic, 29 (44.62\%) articles about women were written.

A total of 123 articles were published in Večernje novosti. Three articles (and two advertisements) were about the holiday, which is $2.44 \%$. In this issue of Večernje novosti, 30 (24.39\%) articles were written about women. 
Table 1 Representation of articles about Women's Day

\begin{tabular}{|c|c|c|c|}
\hline $\begin{array}{c}\text { Newspaper } \\
\text { name }\end{array}$ & $\begin{array}{c}\text { The total number of } \\
\text { published articles }\end{array}$ & $\begin{array}{c}\text { Number of articles } \\
\text { about Women's Day }\end{array}$ & $\begin{array}{c}\text { Percentege of articles } \\
\text { published about } \\
\text { Women's Day }\end{array}$ \\
\hline Politika & 62 & 5 & $8 \%$ \\
\hline Danas & 83 & 11 & $13.2 \%$ \\
\hline Blic & 65 & 0 & $0 \%$ \\
\hline $\begin{array}{c}\text { Večernje } \\
\text { novosti }\end{array}$ & 123 & 3 & $2.4 \%$ \\
\hline
\end{tabular}

Table 2 Representation of women in articles

\begin{tabular}{|c|c|c|c|}
\hline $\begin{array}{c}\text { Newspaper } \\
\text { name }\end{array}$ & $\begin{array}{c}\text { The total number of } \\
\text { published articles }\end{array}$ & $\begin{array}{c}\text { Number of published } \\
\text { articles about women }\end{array}$ & $\begin{array}{c}\text { Percentege of articles } \\
\text { published about women }\end{array}$ \\
\hline Politika & 62 & 13 & $21 \%$ \\
\hline Danas & 83 & 22 & $26.5 \%$ \\
\hline Blic & 65 & 29 & $44.6 \%$ \\
\hline $\begin{array}{c}\text { Večernje } \\
\text { novosti }\end{array}$ & 123 & 30 & $24.4 \%$ \\
\hline
\end{tabular}

One of the initial assumptions was that Politika reported on the holiday in the manner that emphasized the fight for equality of women's rights, which was the idea behind the first celebration of the holiday in the world. On the front page of Politika, there was the following headline related to the holiday: Best for Women in Parliament, and Hardest at Home. In the Society section Društvo, the whole page was given to the article with the above headline and the following survey on gender equality: Emancipation Made Their Position More Difficult. The article Best for Women in Parliament, and Hardest at Home deals with gender (in)equality, outlining the statistical data that indicate the dominant status of men compared to women. The article also announced a protest organized on March $8^{\text {th }}$ - If women stop, the whole world stops; we don't want flowers, but a more just world, in order to draw attention to the unequal position of women, as written in the article. Five women's views on gender equality were presented in the survey. In the Region section, there was another article about the holiday under the following headline: International Women's Day Could Become a National Holiday in Slovenia, which also covered women's fight for equality in society.

The Feuilleton section featured the following headline: Browsing Politika. The article refers to the article published in Politika back in 1969 on International Women's Day. The article is about the exhibition Women-creators held at the Museum of Applied Arts on the occasion of International Women's Day. The aim of the exhibition was the desire to ensure a free and creative life for all people, according to Politika. This article from 1969 also demonstrates the long tradition of this newspaper, characterized by a serious approach to topics of social importance. 
The article Reading on the Eighth of March was published in the Culture section in the form of an announcement of a meeting of the same name organized by the Serbian Literary Society on the occasion of International Women's Day.

Advertisements and classifieds were not considered as units of analysis in quantifying the general presence of women in the daily newspapers on the day of the holiday. However, the advertisements and classifieds about the holiday were considered. The headline All Episodes of "Mrs. Wilson" for International Women's Day was published in the form of an advertisement in the TV programme section.

No article about the holiday in Politika was published following the "celebratory level" model. However, when it comes to the general presence of women on the day of the holiday, Politika devoted only $21 \%$ to articles about women, suggesting that women are marginalized in Politika.

In the daily newspaper Danas, as many as 11 articles were about the holiday, as well as a special column Women's Day on pages 14 and 15, which contained 4 articles. Danas also gave space to International Women's Day on its front page with the following headline: Purple Aprons on the Monuments of Outstanding Persons (and the heading: Feminist Activities on International Women's Day). The article discusses the protest of feminists and their intention to draw attention to the invisibility of women's rights, in science, among other things. On the same page, in the Women's Day section, there was a personal stance of the Council of Europe Commissioner for Human Rights, with the headline: Gender Equality Is a Core Value. Two other headlines in the Women's Day section were the following: Diversity Has Always Been the Strength of the Balkans and Resistance of Women Means Change. Other headlines of the articles about the holiday were the following: in the Chronicle section, the article Festival of Women's Creativity in Pirot; in the Novi Sad / Sport section, the articles Discussion on the Position of Women and Children Take Moms to Exhibitions; in the Politics section, the article What Is Your Next Move; in the Society section, the article UN: One in Two Women Experienced Psychological Abuse; in the Economy section, the article Car Go Postponed Protest Because of March 8th; and in the Dialogue plus section, the article March 8th in Real Life. In the last mentioned article, the author's opinion is emphasized in the text box, which reads: In real life, the Eighth of March is the complete opposite of what it is supposed to represent. It can hardly be called a day of celebration of women's rights, but rather the day of women - second-class human beings. Its whole essence comes down to flowers in cellophane and all kinds of business celebrations, which many women look forward to as one of the few days when they go out at all. The article especially criticizes the idea of the holiday that is currently dominant, based on apparent affection for women. It is pointed out that the purpose of the holiday is not buying gifts, but "fighting for women's rights".

The analysis of all of the aforementioned articles in Danas shows that there are no elements of reporting on the holiday which follow the "celebratory level" model. However, the figure of $26.51 \%$ of the general presence of women shows that they are marginalized in Danas too.

The articles about the holiday in the daily newspapers Politika and Danas indicate to the public the original character of International Women's Day, as well as 
gender inequality. Selecting topics and emphasizing them on front pages, publishing statistics, creating content and headlines, emphasizing the views of experts and journalists, as well as announcing protests and events related to the holiday express the tendency of Politika and Danas to present the holiday with its original idea women's fight for equal rights.

There were no articles in the daily newspaper Blic indicating that the reason for writing them was International Women's Day. However, in this issue, Blic added nine articles with the common headline Successful Women that cannot be found in other issues, which is why they are assumed to have been included because of the holiday. The articles are in the form of interviews, each occupying half a page and being visually separated from the others. They are in different sections (World, Society, Economy, Entertainment, Culture, Sport), always on the right half of the right page. On the front page of Blic, space is given to the headline Blic Presents Successful Women. Nine articles feature nine successful women in marketing, economics, business, etc. Although in none of the articles the holiday was mentioned as the reason for writing them, in one of the interviews, with the President of IO ProCredit, there was the following heading: ProCredit Bank Offers Everyone Equal Opportunities. It is assumed that the heading was written with the aim to point to inequality between men and women, in terms of (un)equal opportunities.

Another headline of a two-page article in Blic is the following: Magnificent Women Changing the World. The article begins with the sentence: The "Blic zena" magazine has been giving awards to the best women in different fields for 12 years. The article presents ten women with outstanding achievements. The opinions and messages of all the award-winning women are given: pianist, teacher, doctor of neurosurgery, forensic doctor, etc.

Given that no article is about the holiday, it is not possible to interpret reporting from the aspect of the "celebratory level" or the "fight for equality of rights". Although the presentation of 19 successful women in Blic indicates a positive representation of women in this issue, this cannot justify the failure to report on the holiday and its importance. However, writing about successful women in leadership positions, which are more often attributed to men, can be distinguished as a positive fact.

In this issue, Blic had 29 articles about women, or $44.62 \%$, which is a significantly higher percentage compared to $20.97 \%$, or $26.51 \%$ in Politika and Danas. However, one should consider the additional section of Successful Women in Blic, which is not normally found in other issues, so the assumption is that in other issues, the percentage of articles about women is lower than in the issue published on March $8^{\text {th }}$.

In Večernje novosti, there are three articles (one classified advertisement and one advertisement) related to the holiday. The front page features the headline related to the holiday: Gifts as Down Payment for Better Grade. There is also a separate section called Women's Day in Večernje novosti, with 2 articles. The article with the aforementioned headline criticizes the practice of children and their parents buying expensive gifts for educators. On the other half of the page, in the Women's Day section, Večernje novosti has the article about the holiday which discusses the history 
of the holiday and its basic idea. In this article, the headline Voucher Instead of Flower and the heading The tradition of celebrating International Women's Day began 110 years ago show the main motivation behind the holiday - fight for gender equality which is still ongoing. However, in the Advertisement section, a whole page was given to the advertisement with the following title: Give your love most beautiful book about love on March $8^{\text {th }}$. In this advertisement we find the elements of reporting on the holiday which suggest buying gifts and understanding the holiday on the basis of the "celebratory level" model. In the Spotlight section, there is an article titled For Ladies and Gentlemen with the heading Spectacle by Dragana Mirković tonight on Jahorina for March 8. The article announced the concert of the above-mentioned singer, without any elements of interpretation of the holiday. The headline Power of the Fairer Sex with the heading Films and TV shows on International Women's Day represents an advertisement in Večernje novosti, which begins with the following sentence: On International Women's Day, through documentaries and feature films, we will remind ourselves of the icons offemale power and fight... Although the text is in the form of an advertisement, the holiday is here associated with female power and fight, which can be interpreted as positive from the aspect of representation of the holiday.

There were 30 articles about women in Večernje novosti, which represents, in relation to the total number of articles (123), the approximate percentage (24.39\%) of their frequency as in Politika and Danas.

\section{Concluding Remarks}

Gender inequality has been a major social problem in the world throughout history. Therefore, the idea of fighting for women's rights is especially important, which is also the idea behind the first celebration of International Women's Day in the world. The task of the media, as the guardian of the public interest, is to indicate the importance of the original idea of the holiday, with the aim of raising social awareness of the main motivation behind International Women's Day. The manner of the representation of the holiday in the media and the frequency of reporting on women may affect their position in society.

The research showed that the print media analyzed reported on the holiday in a manner that addresses the idea behind the first celebration of the holiday in the world - fight for women's rights. However, by comparing the informative daily newspapers (Politika and Danas) and the semi-tabloids (Blic and Večernje novosti), differences in reporting were observed. In Politika and Danas, there was the greatest number of articles about the holiday. In these newspapers, all articles were thoughtfully written, from a socially relevant point of view, with no elements of reporting that promote the new symbolism assigned to the holiday. On the other hand, Večernje novosti had the elements of reporting in which the meaning of the holiday was associated with buying gifts. However, it is important to conclude that in Večernje novosti, a critical attitude towards the "celebratory level" of the holiday also prevails, and that in the special section Women's Day, there are articles that refer exclusively to the critique of 
gender inequality. It was not stated in any article in Blic that the reason for writing them was the holiday. Presenting nineteen successful women can be understood as positive, but neglecting to write about the importance of the holiday alludes to the social as well as professional irresponsibility of Blic.

When it comes to the frequency of articles about women, women are marginalized in all analyzed newspapers. The results of the research show that their presence, at the level of all analyzed print media, is less than one third (28.23\%) compared to the total number of articles. A disturbing fact is that the marginalization of women in the media continues, despite studies that show and criticize the low presence of women in articles in the media. Therefore, it is necessary to constantly point out to the low presence of women in the media in order to increase their quantitative presence. The qualitative presence of women in the media is especially important, since the choice of topics and the manner of reporting may restrict stereotypes and discriminatory attitudes. In this way, the media would contribute to the women's fight for equal rights that started in 1910 in Copenhagen.

\section{References}

Baćević, J. (2007). „Dan zaljubljenih kao Osmi mart tranzicione Srbije“. Glasnik Etnografskog instituta SANU, 55(1), pp. 77-89. URL: http://www.doiserbia.nb.rs/img/ doi/0350-0861/2007/0350-08610701077B.pdf

Balkovec, B. (2016). „Izborno zakonodavstvo prve jugoslavenske države (1918.-1941.)“. Časopis za suvremenu povijest, 48(1), pp. 197-216. URL: https://www.researchgate. net/profile/Bojan_Balkovec/publication/317026324_Electoral_legislation_of_the_ first_Yugoslav_state_1918_-_1941/links/5a85327ba6fdcc201b9f34e8/Electorallegislation-of-the-first-Yugoslav-state-1918-1941.pdf

Begović, B. (2015). „Upotreba rodno osetljivog jezika i prikaz žena u štampanim medijima u Srbiji“. CM Komunikacija i mediji, 10(35), pp. 59-79. URL: http://www.fpn.bg.ac.rs/ arhiva/sites/default/files/docs/cm35-web.pdf\#page $=59$

Berković, D. (2009). „Od mizoginije do kulta: Etiološko čitanje Postanka 3“. Kairos, 3(2), pp. 305-320. URL: https://hrcak.srce.hr/42325

Brigs, A., Kobli, P. (2005). Uvod u studije medija. Beograd: Clio.

Čolović, I. (1972). „Dan za mušku finoću“. Mitoanaliza jednog praznika. Delo XVIII, 7, pp. 891-896.

Hall, S. (1982). „The rediscovery of 'ideology'; return of the repressed in media studies“. Culture, society and the media (Vol. 759), pp. 52-86. URL: http://didik.mercubuanayogya.ac.id/wp-content/uploads/2014/03/Culture-Society-and-the-Media.pdf

Hall, S. (2001). „The spectacle of the other“. Discourse theory and practice: A reader, pp. 223-90.

Juka, S., Bilaver, I. P. (2013). „Identitet žene - antropološka i medijska slika“. Kultura komuniciranja-znanstveno stručni godišnjak, pp. 11-31. URL: https://www. researchgate.net/profile/Zoran_Tomic4/publication/326068697_Odnosi_s_ 
javnoscu_na_sveucilistu/links/5b366d4eaca2720785f8d6b2/Odnosi-s-javnoscu-nasveucilistu.pdf\#page $=11$

Lippman, W. (1956). Public Opinion. New York: Macmillan.

McQuail, D. (1977). „The influence and effects of mass media“. Mass communication and society, pp. 70-94. URL: http://www.comsci.uzulu.ac.za/Downloads/Main\%20 Campus/Media\%20Studies\%20ACOM232/2014/the\%20influence\%20and\%20 effects\%20o.pdf

McQuail, D. (2005). „Publication in a free society: the problem of accountability“. Comunicação e Sociedade, 7, pp. 235-252.

Melki, J., Farah, M. (2014). „Educating media professionals with a gender and critical media literacy perspective: how to battle gender discrimination and sexual harassment in the media workplace“. Media and gender: a scholarly agenda for the global alliance on media and gender, pp. 74-78. URL: http://www.unesco.org/new/fileadmin/MULTIMEDIA/ HQ/CI/CI/pdf/publications/media_and_gender_scholarly_agenda_for_gamag.pdf

Milošević, L. (2004). „Srbi o drugima, društvena udaljenost Srba od pripadnika drugih naroda, nacionalnih manjina i etničkih grupa u jugoistočnoj Srbiji“. Kvalitet međuetničkih odnosa, svest o regionalnom identitetu i mogućnosti saradnje i integracije na Balkanu, pp. 95-112. URL: http://www.komunikacija.org.rs/komunikacija/knjige/ index_html/knjiga15/09MilosevicL.pdf

Montiel, A. V. (2014). „Violence against women and media: advancements and challenges of a research and political agenda". Media and gender: a scholarly agenda for the global alliance on media and gender, pp. 15-19. URL: http://www.unesco.org/new/fileadmin/ MULTIMEDIA/HQ/CI/CI/pdf/publications/media_and_gender_scholarly_agenda_ for_gamag.pdf

Penezić, Z., Šunjić, M. (2013). „Mediji, ženska rodna uloga i rodni stereotipi“. Kultura komuniciranja-znanstveno stručni godišnjak, pp. 77-92. URL: https://ff.sum.ba/sites/ default/files/casopisi/Kultura\%20Komuniciranja\%20br\%202.pdf\#page=77

Petrović, J. (2012). „Pregled odnosa društva prema osobama sa invaliditetom kroz istoriju“. Teme-Časopis za Društvene Nauke, (02), pp. 865-886. URL: http://teme2.junis.ni.ac. rs/public/journals/1/previousissues/teme2-2012/teme\%202-2012-25\%20lat.pdf

Prajs, S. (2011). Izučavanje medija 2. Beograd: Clio.

Radović, V., Cvetanović, I., Vidojković, D. (2014). „The discourse of public communication in the field of confrontation of PR management and media“. International scientific journal of media, communication, journalism and public relations, pp. 77-90. URL: https://s3.amazonaws.com/academia.edu.documents/36786343/media2.pdf?responsecontent-disposition=inline $\% 3 \mathrm{~B} \% 20$ filename $\% 3$ DComparative_Analysis_of_ Argument_Constru.pdf\&X-Amz-Algorithm=AWS4-HMAC-SHA256\&X-Amz-Cre dential=AKIAIWOWYYGZ2Y53UL3A\%2F20200315\%2Fus-east-1\%2Fs3\%2Faws4_ request $\& X-A m z-D a t e=20200315 T 220008 Z \& X-A m z-$ Expires $=3600 \& X-A m z-$ SignedHeaders $=$ host $\& X-A m z-S i g n a t u r e=b c 4 f 522$ e24eda3b1683507bff17f959136aacda 2bbc0402ce7a0974b06a3830d\#page $=78$

Sarikakis, K. (2014). „Power, patriarchy, profit: barriers to gender mainstreaming in media policy“. Media and gender: a scholarly agenda for the global alliance on media and gender, pp. 66-69. URL: http://www.unesco.org/new/fileadmin/MULTIMEDIA/HQ/ CI/CI/pdf/publications/media_and_gender_scholarly_agenda_for_gamag.pdf 
Slavnić, D. N. (2011). „Medijska reprezentacija grupnih identiteta“. CM Komunikacija $i$ mediji, 6(19), pp. 15-37. URL: https://www.academia.edu/40227151/Medijska_ reprezentacija_grupnih_identiteta

Stjepanović-Zaharijevski, D. (1999). Moć i nemoć žene. Niš: Prosveta.

Stuart Mill, J. (2000). Podređenost žena. Zagreb: Hrvatsko sociološko društvo.

Šinko, M. (2007). „Žene u parlamentima-globalna perspektiva“. Politička misao: časopis za politologiju, 44(2), pp. 71-92. URL: https://hrcak.srce.hr/20643

Torlak, N. (2011). „Medijska slika žene u Srbiji“. CM Komunikacija i mediji, 6(19), pp. 39-52. URL: http://www.fpn.bg.ac.rs/arhiva/sites/default/files/wp-content/uploads/ CM19-Web.pdf

Vasiljević, L. (2009). Drugost u medijima: slika žene u dnevnoj i nedeljnoj štampi - priručnik za medije. Beograd: Ženski INDOK centar.

Višnjić, J. (2016). „Rodna analiza teksta u online štampanim medijima u Srbiji“. Doktorksa disertacija. Novi Sad: Univerzitet u Novom Sadu. URL: http://nardus.mpn.gov.rs/ bitstream/handle/123456789/7754/Disertacija8049.pdf?sequence=1\&isAllowed=y

Višnjić, J., Mirosavljević, M. (2008) „Problem reprezentacije roda u medijima“. Neko je rekao feminizam?KakojefeminizamuticaonaženeXXIveka,pp.248-263.URL:http://rifdt.instifdt. bg.ac.rs/handle/123456789/1329;jsessionid=0F017273B01C3D8A811E2C2AF2F6E82C

Vujović, M. (2016). „Komparativna analiza reklamne fotografije i reprezentacije roda u socijalističkoj i tranzicijskoj Srbiji“. Doktorska disertacija. Beograd: Univerzitet umetnosti u Beogradu. URL: http://nardus.mpn.gov.rs/handle/123456789/9648

Vujović, M., Milovanović, I. (2014). „Vizuelna reprezentacija žene u ženskoj štampi“. Digitalne medijske tehnologije i društveno obrazovne promene 4, pp. 121-132. URL: http://digitalna. ff.uns.ac.rs/sites/default/files/db/books/978-86-6065-308-8.pdf\#page=121

Vujović, M., Obradović, N., Mitrović, M. (2014). „Marginalizacija žena u štampi“. Jezik, književnost, marginalizacija: jezička istraživanja, pp. 107-117.

Zaharijević, A., Lončarević, K. (2011). Osmi mart: istorija jednog „praznika“. Beograd: Ženski informaciono-dokumentacioni centar.

\title{
PREDSTAVLJANJE MEĐUNARODNOG DANA ŽENA U SRPSKOJ ŠTAMPI
}

\begin{abstract}
Apstrakt: Čovekova pažnja usmerena je na događaje, pojave, ličnosti $i$ društvene grupe zastupljene u medijima. Način njihove percepcije zavisi od medijske prezentacije, odnosno reprezentacije koja podrazumeva medijske predstave dogadaja, pojava, identiteta, društvenih grupa. Mogućnosti medija su da posredstvom njih oblikuju javno mnjenje, upućuju na stereotipne i diskriminatorne stavove u društvu, ili ih ograničavaju. Jedan od osnovnih uslova suzbijanja diskriminacije je ravnopravno sudelovanje žena u medijskom svetu, odnosno podjednaka zastupljenost žena i muškaraca u medijima. $U$ radu istražujemo zastupljenost žena u dnevnim novinama Politika, Danas, Blic $i$ Večernje novosti na praznik Međunarodni dan žena, sa posebnim osvrtom na način izveštavanja o prazniku. Teorijski deo rada obuhvata poglavlje o društvenom statusu
\end{abstract}


žene kroz istoriju, u kome su predstavljeni neki od činilaca inferiornog položaja žene, koji su uticali na stvaranje stereotipa o ženi. Zatim je pažnja posvećena stereotipima o ženi, dominantnim medijskim obrascima izveštavanja o ženskom rodu, kao i značaju $i$ istoriji nastanka praznika. U teorijskom delu su predstavljena i tumačenja prethodnih istraživanja iz objavljenih naučnih radova. Drugi deo rada obuhvata kvantitativni $i$ kvalitativni prikaz rezultata istraživanja. Na kraju su sumirani rezultati na osnovu kojih je izveden zaključak.

Ključne reči: mediji, Međunarodni dan žena, marginalizacija, stereotipi, medijska reprezentacija 